\title{
Quantifying surface water on Santa Rosa Island, California, following a major five-year drought
}

\author{
Paula POWER ${ }^{1, *}$ and Rocky Rudolph ${ }^{1}$ \\ ${ }^{1}$ Channel Islands National Park, 1901 Spinnaker Drive, Ventura, CA 93001
}

\begin{abstract}
Although it is critical for survival of plants and animals, and for understanding prehistory of early humans, little work has been done on the stream hydrology of the California Channel Islands. In September 2014, August 2016, and October 2017, during the driest period of the year, park staff and volunteers mapped surface water on Santa Rosa Island, Channel Islands National Park, by walking drainages (2nd order and higher) and recording the location of surface water using consumer-grade Global Positioning System (GPS) units. In 2014, mappers hiked $293 \mathrm{~km}$ (182 miles) of stream channel in 19 major drainage basins and 7 lesser drainage basins. The hiking teams recorded 759 water features (pools and springs) and $67 \mathrm{~km}$ (42 miles) of surface water. The 2016 repeat mapping in Verde, Trancion, Arlington, and San Augustin canyons, the 4 wettest drainages in 2014, showed that surface water declined by $10.1 \%$, $21.1 \%$, and $34.2 \%$ for the first 3 canyons, respectively; surface water in San Augustin increased by 1.3\% between 2014 and 2016. Repeat mapping in 2017 of Verde, Trancion, Arlington, San Augustin, and Water canyons showed an increase from $28.3 \%$ to $90.0 \%$ in surface water following an above-average rainfall year in 2016-2017. Results have important implications for plant and animal life that depend on water on Santa Rosa Island.
\end{abstract}

REsumen.-A pesar de ser un tema crucial para las plantas, los animales y para comprender la historia de los inicios de la humanidad, pocos estudios se han realizado acerca de la hidrología de las corrientes de las Islas del Canal (Channel Islands) de California. En septiembre de 2014, agosto de 2016 y octubre de 2017, durante el período de mayor sequía en el año, el personal del parque y algunos voluntarios mapearon la superficie acuática de la isla Santa Rosa del Parque Nacional de las Islas del Canal, mediante el recorrido de sus drenajes (de segundo orden y superior) y registrando la ubicación de la superficie acuática, usando unidades de Sistema de Posicionamiento Global (GPS por sus siglas en inglés). En 2014, los cartógrafos recorrieron 293 km (182 millas) de cauce en 19 cuencas de drenaje principales y 7 cuencas de drenaje secundarias. Los equipos de recorrido registraron 759 propiedades del agua (estanques y manantiales) y $67 \mathrm{~km}$ (42 millas) de superficie acuática. En el año 2016, los mapeo repetidos en los cañones Verde, Trancion, Arlington y San Augustin (los cuatro drenajes más húmedos del 2014), mostraron que la superficie de agua disminuyó en un $10.1 \%, 21.1 \%$ y $34.2 \%$ respectivamente. La superficie de agua en San Augustin aumentó en un 1.3\% entre 2014 y 2016. Los mapeos repetidos en el año 2017 en los cañones Verde, Trancion, Arlington, San Augustin y Water, mostró un incremento de la superficie de agua del $28.3 \%$ al $90.0 \%$, luego de un año de lluvias superior al promedio en el período 2016-2017. Los resultados tienen importantes implicaciones en la vida de las plantas y de los animales que dependen del agua en la isla Santa Rosa.

Channel Islands National Park comprises 5 Pacific Ocean islands located 20 to $61 \mathrm{~km}$ offshore from southern California. The islands span a major transition in climate on the California coastline where the cool waters of the California Current from the north meet the warm waters of the Inshore Countercurrent from the south (Hendy 2010). The islands are located in a semiarid to subhumid Mediterranean climate characterized by cool, wet winters and warm, dry summers with high year-to-year variability. Winter precipitation shows more relative year-to-year variation along the southern California coast than anywhere else in the United States; rainfall ranges from approximately $20 \mathrm{~cm}$ (8 inches) to $100 \mathrm{~cm}$ (40 inches) per year (Redmond and McCurdy 2005).

Climate is a fundamental driver of biological and physical systems, yet until the development of the long-term weather monitoring program by the National Park Service in the mid-1980s, there was little consistency among the islands in how weather was measured and

*Corresponding author: paula_power@nps.gov 


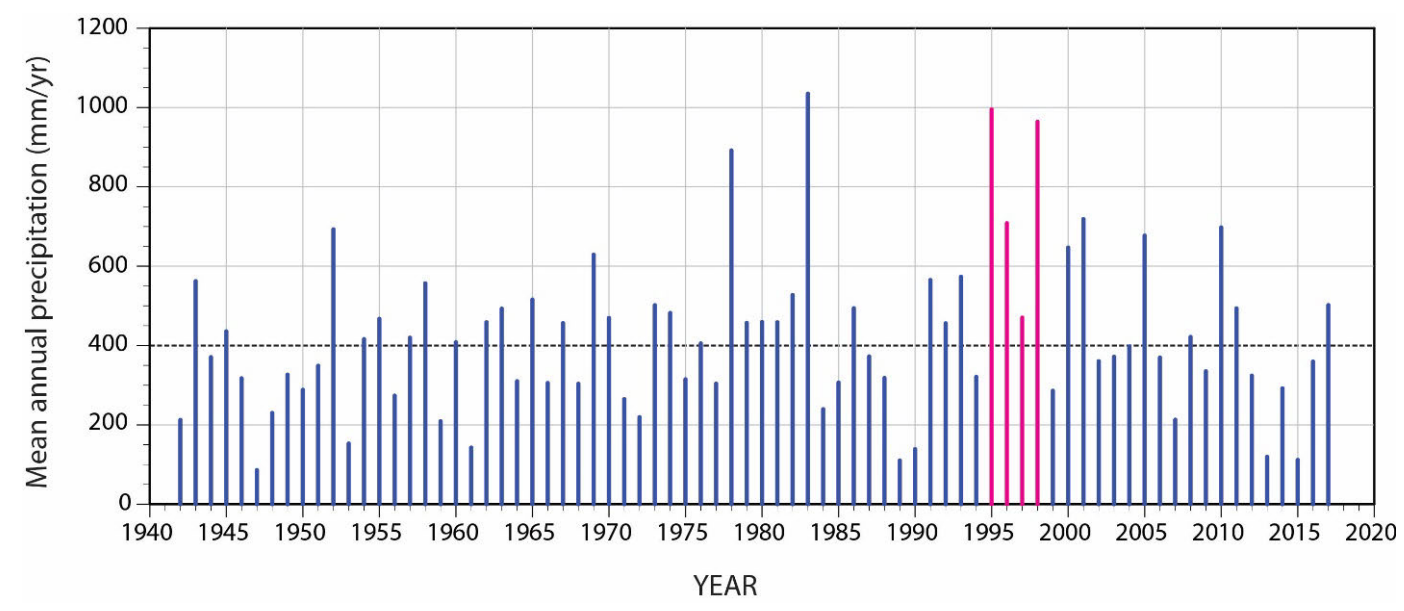

Fig. 1. Mean annual precipitation from 1942 to 2017 at Santa Barbara Airport, Santa Barbara, California. Between 1995 and 1998, values were taken from Santa Barbara Harbor because airport records were incomplete at that time. Period-of-record annual mean precipitation is $40 \mathrm{~cm}$ (15.75 inches) per year.

recorded (Richards 1997) and little to no documentation of the surface water hydrology of Channel Islands National Park.

\section{Santa Rosa Island}

Santa Rosa Island (21,700 ha [84 miles $\left.\left.{ }^{2}\right]\right)$, located $50 \mathrm{~km}$ (31 miles) southwest of Santa Barbara, California, is the second largest island in Channel Islands National Park. It is characterized by highly incised canyons, marine terraces, sandy beaches, and 3 centrally located peaks: Radar Mountain $(484 \mathrm{~m}$ [1589 ft.]), Soledad Mountain (480 m [1574 ft.]), and Black Mountain (395 m [1298 ft.]).

The climate of Santa Rosa Island is characterized by cool, wet winters, and warm, dry summers, apart from fog drip (Williams et al. 2008). Springs and pools, and surface water, are natural resources critical to Santa Rosa Island, where $95 \%$ of precipitation (averaging about $36 \mathrm{~cm}$ or 14 inches per year) occurs between November and April and is highly variable and unpredictable (Fig. 1; Redmond and McCurdy 2005). Precipitation, surface runoff, fog input, and evapotranspiration of plants control groundwater levels and recharge. Groundwater discharge (springs) provides base flow to the island's 19 major creeks. These creeks support rare plant species including Pinus torreyana and Quercus tomentella; provide valuable riparian habitats for Santa Rosa Island foxes (Urocyon littoralis ssp. santarosae), birds (Collins 2011), and herpetofauna; and enhance the visitor experience with their scenic quality. The island's creeks are often locations of exceptional beauty and may have had cultural significance for Native Americans who occupied the island for more than 12,000 years (Johnson et al. 2000).

The ranching era began on Santa Rosa in 1844. At that time, nonnative ungulates, including cattle, sheep, pigs, deer, and elk, were brought to the island, and the subsequent 150 years of intensive grazing negatively impacted native coastal sage scrub, island chaparral, grassland, and scattered oak and pine woodland plant communities. The effect of intensive grazing may have also affected hydrologic processes through increased runoff and reduced groundwater input. The park removed all nonnative grazers between 1993 and 2011 (Lombardo and Faulkner 1999), and recovery of wildlife and plants, including the Santa Rosa Island fox and Torrey pine (Pinus torreyana ssp. insularis), is occurring.

With rapid change taking place following removal of all nonnative ungulates, there was a need to better characterize Santa Rosa Island's surface water hydrology. In September 2014, during a historic 5-year drought (from spring 2012 through January 2017; Table 1), park staff and volunteers mapped all pools, springs, and streams by systematically walking 293 stream kilometers (182 miles) along all streams of 2 nd order or greater (Horton 1945, Strahler 1957, Fitzpatrick et 


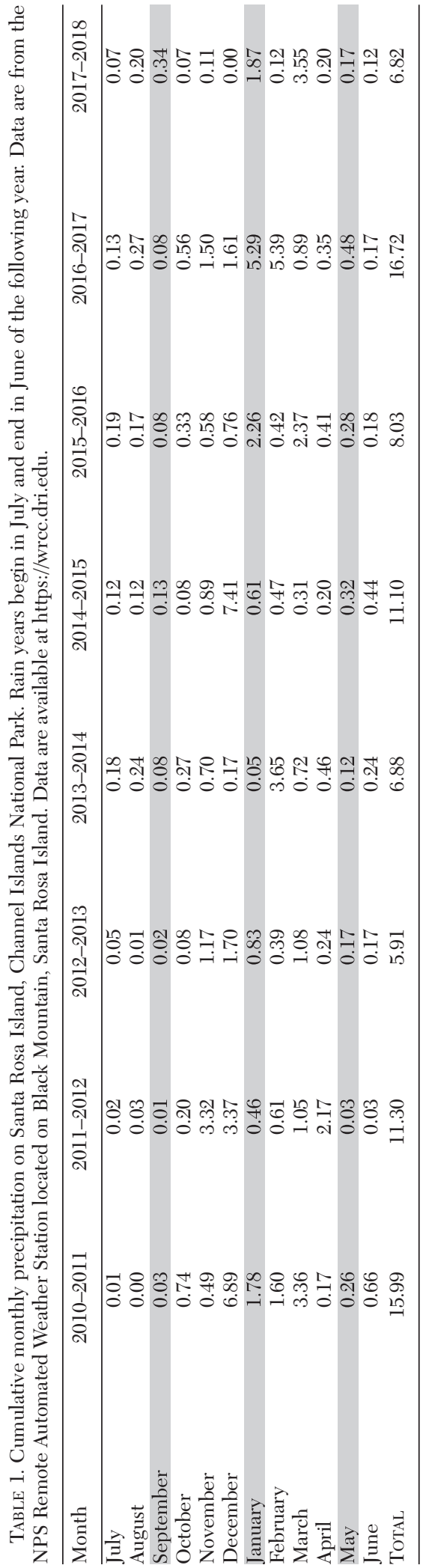

al. 1998, Turner and Richter 2011). It was not practical to systematically map 1st-order streams due to the steep terrain. In August 2016, following 39 months of drought, park staff remapped 4 of the drainages for comparison with the 2014 survey (Table 1). In October 2017, following a slightly greater-than-average rain year in 2016-2017, park staff remapped 5 drainages (Table 1). We chose to physically walk tributaries rather than relying on digital data sets or aerial photos to determine the extent of surface water. Although time consuming and labor intensive, this approach resulted in more accurate mapping of hydrologic features and eliminated inaccuracies inherent in digital data sets of different resolutions (Vance-Borland et al. 2009).

\section{Methods}

Over 2 weeks in September 2014, park staff and volunteers systematically mapped all surface water features during the driest time of year to establish baseline hydrologic data (see Turner and Richter 2011). This effort involved identifying all drainage basins and all streams of 2nd order or higher (Horton 1945, Strahler 1957, Fitzpatrick et al. 1998); creating a unique identifier for each basin and tributary; and assigning tributaries to teams of 2 mappers equipped with a Garmin ${ }^{\circledR}$ GPS (3-5 m accuracy $95 \%$ of the time using Wide Area Augmentation System [WAAS] in North America), a camera, a radio, paper data sheets, and reference maps to locate and record locations for all water features. In August 2016, park staff remapped Verde, Arlington, Trancion, and San Augustin canyons using the same procedure. In October 2017, the above canyons plus Water Canyon were remapped using the same procedure. Basins were given the same name as the trunk stream draining the basin. Small, adjacent basins without a major creek name were given the same name as the neighboring basin followed by a sequential number (e.g., Garañon 1).

Multiple teams walked creek bottoms and recorded locations for each pool, spring, and surface water feature. Pools were defined as any standing surface water $<1 \mathrm{~m}(3 \mathrm{ft}$.) in length. Springs were defined as points where water clearly emerged from the ground but remained on the surface for $<3 \mathrm{~m}$ (10 ft.) or connected to the associated trunk stream. If 

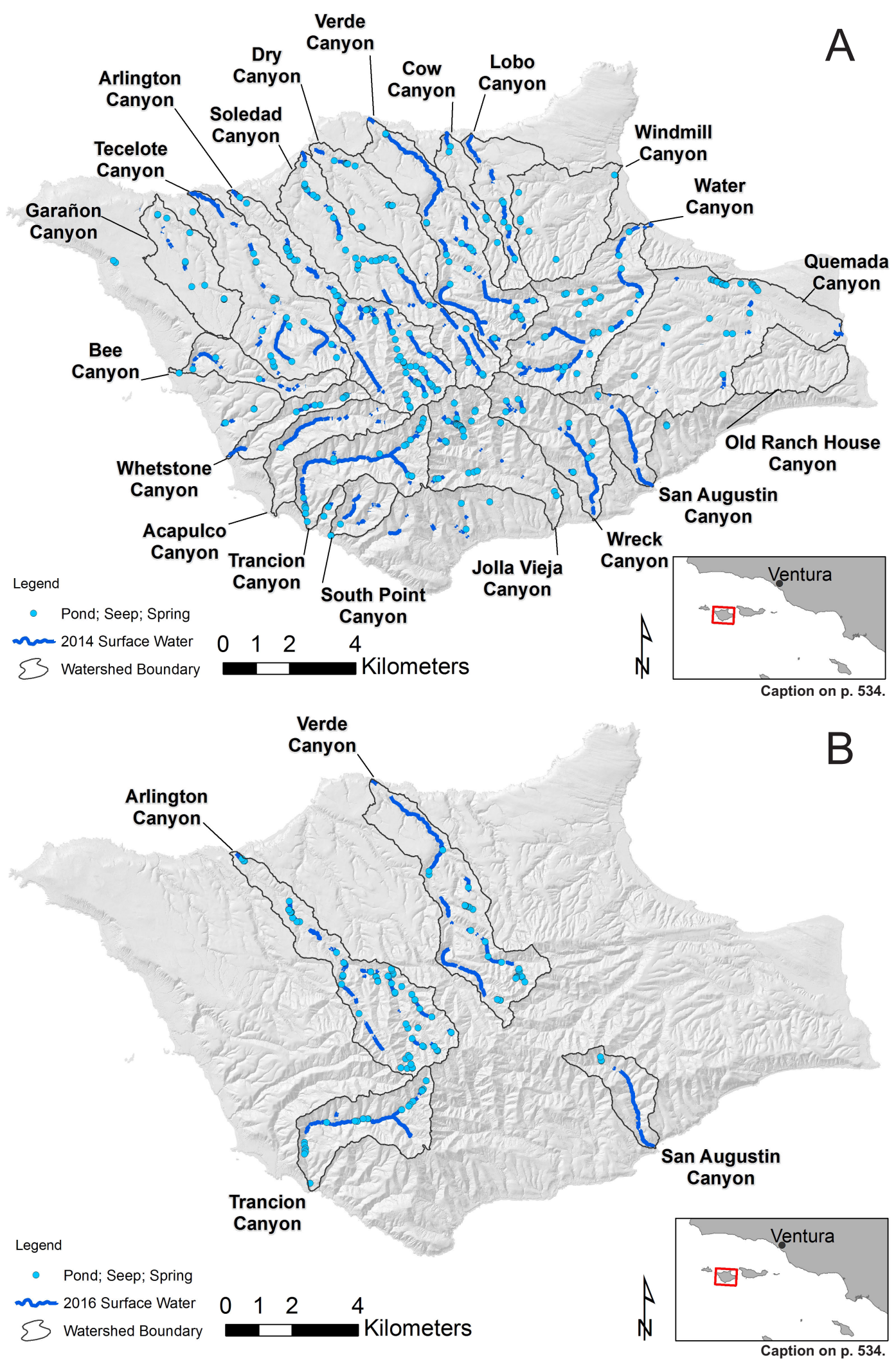


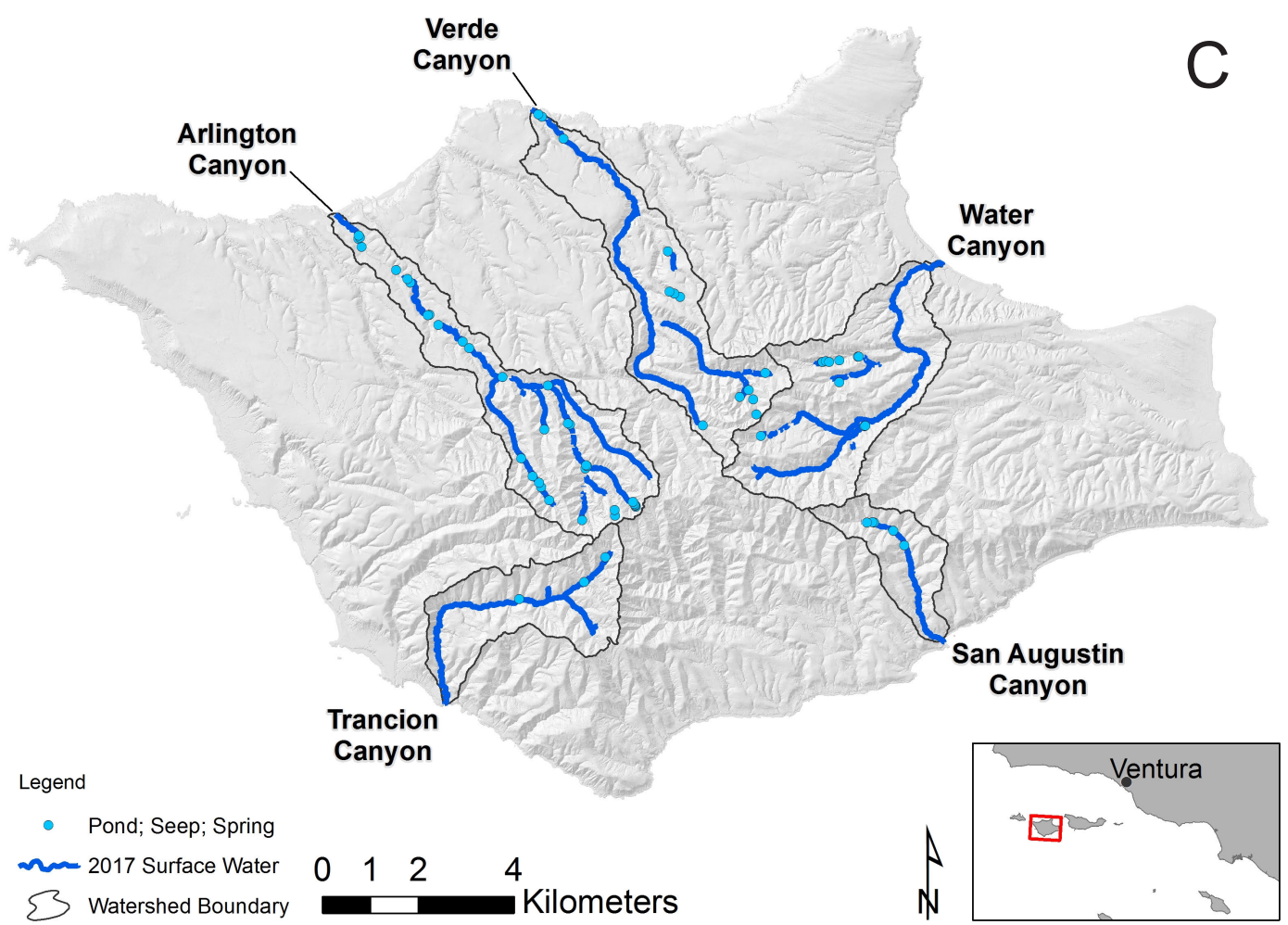

Fig. 2. Location of surface water and pools and springs on Santa Rosa Island, Channel Islands National Park, California: A, 2014; B, 2016; C, 2017.

surface water was present continuously for $3 \mathrm{~m}$ $(10 \mathrm{ft}$.) or more, locations of the beginning and end of these wetted reaches were recorded. Teams also recorded the locations of significant cultural finds, specific invasive species populations, significant bird sightings or any other unusual sightings. Significant features were photographed with GPS-enabled cameras.

At the end of each day, team members submitted paper data sheets, GPS units, and other equipment to the data manager. The data manager then downloaded and checked the data against hand-recorded data from the paper data sheets, which served as the first level of data quality assurance. All recorded points and track logs were loaded into a geodatabase using a semiautomated script run by the data manager.

For the purposes of describing drainage basin characteristics, segments of surface water between stop/start points were considered perennial. We assumed surface water was perennial because mapping took place during the driest time of year in an extreme 3- to 5-year drought. Each basin was characterized further using the following geomorphic descriptors. Drainage area for a specific basin was measured in a horizontal plane, enclosed by a drainage divide (Horton 1945). The cumulative perennial (wetted) stream length is the sum of the lengths of all perennial (wetted) stream segments in all tributaries of 2 nd order or greater within a drainage basin (Horton 1945). We computed a new measurement that is a variation on the classic concept of drainage density, defined as total stream length divided by drainage basin area (Leopold et al. 1964). Here we introduce the concept of "wetted drainage density," which is the ratio of the cumulative perennial (wetted) stream length to drainage basin area.

Water features were rare in 1st-order streams and were only mapped if the location was accessible and the mapper believed the feature was ecologically significant. Because of this mapping inconsistency, 1st-order streams are not included in the analysis. However, Fig. 2 includes water features in 1st-order 
TABLE 2. Results from 2014 stream mapping of major and minor basin drainages on Santa Rosa Island, Channel Islands National Park, California.

\begin{tabular}{|c|c|c|c|c|}
\hline Basin & $\begin{array}{l}\text { Drainage area } \\
\text { (ha) }\end{array}$ & $\begin{array}{l}\text { Cumulative } \\
\text { wetted stream } \\
\text { length }(\mathrm{m})\end{array}$ & $\begin{array}{l}\text { Wetted channel } \\
\text { length: drainage } \\
\text { basin area (m:ha) }\end{array}$ & $\begin{array}{c}\text { Total pools } \\
\text { and springs }\end{array}$ \\
\hline Verde & 1183.04 & 10545 & 8.91 & 13 \\
\hline Trancion & 735.92 & 5998 & 8.15 & 18 \\
\hline San Augustin & 367.85 & 2969 & 8.07 & 0 \\
\hline Arlington & 1181.61 & 9105 & 7.71 & 52 \\
\hline Water & 1219.63 & 7413 & 6.08 & 24 \\
\hline Soledad & 1225.83 & 7134 & 5.82 & 33 \\
\hline Wreck & 741.81 & 3985 & 5.37 & 8 \\
\hline Acapulco & 474.67 & 2390 & 5.04 & 1 \\
\hline South Point 1 & 248.16 & 1224 & 4.93 & $\begin{array}{l}1 \\
3\end{array}$ \\
\hline Tecolote & 1183.90 & 5704 & 4.82 & 15 \\
\hline Lobo & 470.34 & 2244 & $\begin{array}{l}4.02 \\
4.77\end{array}$ & 6 \\
\hline Whetstone & 276.10 & $\begin{array}{l}2247 \\
1277\end{array}$ & 4.63 & 9 \\
\hline Bee 1 & 366.05 & 1434 & 3.92 & 5 \\
\hline Cow & 278.77 & 1014 & 3.64 & 5 \\
\hline South Point 2 & 168.54 & $\begin{array}{r}1014 \\
492\end{array}$ & $\begin{array}{l}3.04 \\
2.92\end{array}$ & 0 \\
\hline South Point 5 & $\begin{array}{r}100.04 \\
48.51\end{array}$ & 102 & 2.10 & 2 \\
\hline Bee 2 & $\begin{array}{r}40.01 \\
198.01\end{array}$ & 271 & $\begin{array}{l}2.10 \\
1.37\end{array}$ & 4 \\
\hline South Point 4 & 134.64 & 158 & 1.17 & 2 \\
\hline South Point 3 & 176.42 & 175 & 0.99 & 0 \\
\hline Dry & 686.22 & 608 & 0.89 & 16 \\
\hline Jolla Vieja & 930.80 & 790 & 0.85 & 38 \\
\hline Garañon 1 & 618.19 & 445 & 0.72 & 11 \\
\hline Quemada & 1863.76 & 1189 & 0.64 & 26 \\
\hline Garañon 3 & 207.05 & 34 & 0.16 & 1 \\
\hline Windmill & 884.65 & 81 & 0.09 & 6 \\
\hline Garañon 2 & 136.82 & 3 & 0.02 & 2 \\
\hline
\end{tabular}

streams to provide as complete a representation of surface water on Santa Rosa Island as possible.

\section{RESULTS}

All named basins on Santa Rosa Island had surface water except Old Ranch Canyon; therefore, Old Ranch Canyon and smaller, unnamed or dry basins were dropped from further analysis and discussion.

Five drainages with the greatest cumulative perennial (wetted) stream length in 2014 originate near the 2 highest peaks on the island, Soledad and Radar, and drain outward from these uplands. Verde $(10,545 \mathrm{~m}[34,597 \mathrm{ft}]$.$) ,$ Arlington (9105 m [29,872 ft.]), and Soledad $(7134 \mathrm{~m},[23,408 \mathrm{ft}]$.$) drain to the north; Tran-$ cion $(5998 \mathrm{~m}[19,678 \mathrm{ft}$.]) drains to the southwest; and Water (7413 m, [24,323 ft.]) drains to the east (Fig. 2, Table 2). Drainages with the least cumulative perennial (wetted) channel originate at lower elevations and drain to the west, east, and south side of the island and include Garañon (northwest; $445 \mathrm{~m}$ [1460 ft.]) and Windmill drainages (northeast; $81 \mathrm{~m}$ [266 ft.]).
Cumulative perennial (wetted) stream length in 2014 for other well-known drainages included Dry (608 m [1995 ft.]), Jolla Vieja (790 m [2593 ft.]), and Quemada (1189 m [3902 ft.]).

Using data from 2014, canyons with the greatest wetted drainage density were remapped in 2016. Wetted surface and drainage density decreased during this time in all mapped drainages except San Augustin (Table 3, Fig. 2). San Augustin increased in wetted drainage density between 2014 and 2016 from 8.07 to 8.18. In October 2017, eight mappers remapped the above canyons plus Water Canyon. Wetted channel length increased in these drainages between 2014 and 2017 , with the greatest percent change in wetted stream length in Water Canyon $(+90 \%)$ followed by Arlington $(+88.8 \%)$, Trancion $(+49.3)$, Verde $(+47.2)$, and San Augustin $(+28.3)$ (Table 3).

\section{Discussion}

Physically walking all 2nd-order and greater streams was an effective method of obtaining detailed and accurate information 


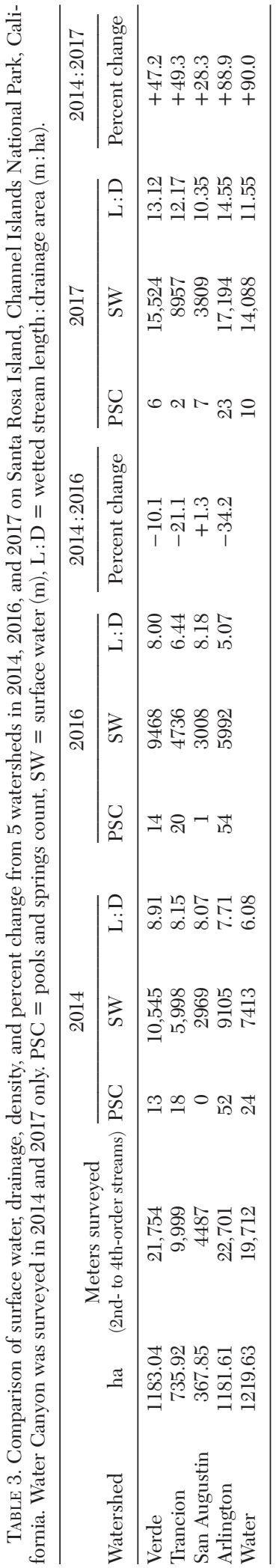

about surface water hydrology on Santa Rosa Island, confirming the location and extent of surface water island-wide. Island managers were familiar with perennial water in the lower reaches of Verde, Arlington, Water, and Lobo canyons, but little was known about perennial water in the upper reaches of basins, the location of water sources, or the relative amount of perennial water across basins.

Wetted drainage density represents the amount of wetted stream length relative to the basin area. Drainage density (in the classic sense, including total stream length whether wetted or not) reflects climate patterns, geology, soils, basin vegetation, and age of the stream network. It is an effective metric for comparing relative water availability across basins and is perhaps the single most useful index to describe basin processes (Gregory and Walling 1973). Drainages radiating outward on the windward side of the highest peaks on the island, where prevailing winds lose their moisture, result in wetter drainages (Verde, Trancion, and Arlington). Drainages originating on the leeward side of mountain peaks tend to be drier because the prevailing winds lose moisture due to the rain shadow effect. Thus, we hypothesize that precipitation likely decreases across the island from west to east, with the least precipitation falling on the east side of the island. Drainages with low drainage density (Quemada, Jolla Vieja, and Windmill) are mostly located to the east or southeast of the center of the island, where relatively less precipitation occurs

Some drainages showed remarkable resiliency following a normal to above-average rain year in 2016-2017. Water and Arlington canyons were relatively dry canyons in 2014 and 2016 compared with Verde, Trancion, and San Augustin, but in 2017 surface water nearly doubled in these canyons $(+90.0 \%$ and $+88.9 \%$, respectively), and Arlington had the greatest wetted basin density of the 5 mapped canyons (14.55 in 2017 compared with 5.07 in 2014). Arlington Canyon had 52 small water features in 2014 and 23 in 2017; Water Canyon had 24 features in 2014 and 10 in 2017. Thus, these 2 canyons had more than double the number of water sources compared to the other mapped canyons combined. The location of springs is associated with geologic features including structure, lithology, and topography (Schmidt et al. 2015, Schumann et al. 2016). 
Potential causal mechanisms for surface water presence on Santa Rosa Island are the subject of ongoing research (Schmidt et al. 2017).

Repeat mapping in 2016 identified the sources of surface water that continued to flow through the extended drought period. Clapp Spring in San Augustin Canyon is notable. This spring, the largest on Santa Rosa Island, emerges at an elevation of $287 \mathrm{~m}(944 \mathrm{ft}$.) in a 1st-order tributary along the ridge separating San Augustin Canyon from Quemada Canyon. Between 2014 and 2016, wetted channel length increased from $2969 \mathrm{~m}$ to $3008 \mathrm{~m}-\mathrm{a}$ surprising observation during a drought. Water from Clapp Spring is routed by gravity through a pipe from the springhouse at the source to a concrete watering trough constructed in 1953 on the Sierra Pablo road located on the ridge separating San Augustin from Quemada drainage (Livingston 2016). Originally, overflow water was diverted from the concrete tank to Quemada Canyon. In 2015 overflow water from the concrete tank was rerouted back to San Augustin Canyon, delivering water to its basin of origin. It is possible that rerouted water contributed to the additional surface water observed in 2016. At present, Quemada no longer receives additional water from Clapp Spring.

The number of pools and springs on the island increased in 2016 compared with 2014. The slight increase in the number of small water features $<3 \mathrm{~m}(\sim 10 \mathrm{ft}$.) in length (Table 3) is likely due to lengths of water shrinking from the drought and no longer meeting the 3-m threshold for surface water, thus being recorded as ponds or springs. Conversely, the number of pools and springs declined in 2017. This is likely due to the lengthening of surface water segments. Springs which were distinct during drought years were indistinguishable from surface water segments and recorded as surface water in 2017.

During the ranching era, from 1844 to 2011, land management practices negatively impacted native plant communities, resulting in reduced vegetation cover, increased bare ground, and increased soil erosion (Cole and Liu 1994, Anderson et al. 2010). Following the removal of pigs and cattle in the 1990s and the last of the deer and elk in 2011, native vegetation has shown signs of recovery, although recovery has been uneven, with some vegetation types and locations recovering more quickly than others (Johnson and Rodriguez 2001, Wagner et al. 2004). Drainage density (in the classic sense of total stream length, wetted or unwetted, per unit area) determines the amount of stream habitat within the basin and may explain, in part, uneven vegetation recovery patterns across the island (Price et al. 2011). Recovery of island vegetation will contribute to the resiliency of drainages to drought cycles in the future by increasing infiltration and groundwater recharge. Vegetation recovery will be more important in the future as drought cycles are predicted to become more extreme as climate change progresses (IPCC 2013). Stream mapping will provide an important baseline against which future hydrologic processes and water resources can be measured.

Stream mapping had benefits beyond improving our understanding of hydrologic conditions and processes. Surface water is an important resource for wildlife, potentially influencing home range and local population density of the Santa Rosa Island fox and the island skunk (Dillon 2018). Most of the canyons had never been systematically surveyed by investigators on foot, although the potential to locate resources is always an important goal in management of National Park Service land. For example, mappers in the present study were instructed to record the location of incipient noxious weeds, rare plant species, or significant cultural material. During the mapping, one particularly noxious, incipient weed (Helichrysum sp.) was identified in 3 drainages and immediately removed. A number of new populations of invasive fennel were recorded and immediately treated. And finally, a rare mammoth fossil was observed and reported during the survey. This observation led to the major excavation of a well-preserved fossil mammoth skull of considerable scientific significance (Carlson 2016) because the estimated age of the fossil coincides with the age of Arlington Man, the oldest human skeletal remains in North America (Johnson et al. 2000).

\section{Conclusions}

Stream mapping is an effective method of obtaining detailed and accurate information about surface water hydrology on Santa Rosa Island. These data have broad applications 
across many disciplines. Repeated surface water mapping will provide data for trend analysis and create an accurate measure of change in biologic/hydrologic resources (Turner and Richter 2011). It will also inform geologic/hydrologic/biologic interactions (Minor et al. 2013, Schmidt et al. 2015), characterize areas for ecological research (Turner and List 2007), and possibly indicate potential longterm use by prehistoric Native Americans.

\section{Supplementary Material}

Archiving of a supplementary geodatabase is pending on the Integrated Resource Management Applications (IRMA) Portal of the National Park Service (https://irma.nps.gov/ Portal/). The geodatabase contains derived stream lengths; stream start and stop points; and pond, seep, and spring location data.

\section{ACKNOWLEDGMENTS}

The authors would like to thank Ken Niessen for developing a basin- and streamorder model; Stacey Osterman-Kelm, NPS MEDN I\&M Coordinator, and Lena Lee, MEDN I\&M Data Manager, for technical support; Stephen Bednar for digitizing the stream lengths into a geographic information system (GIS); and the volunteers and park staff who hiked and mapped each canyon. Funding for this project was provided by the National Park Service Mediterranean Network Inventory and Monitoring Program. We also thank reviewers Randy Schumann, Scott Minor, and Dan Muhs (all U.S. Geological Survey) for helpful comments on an earlier version of this manuscript.

\section{Literature Cited}

Anderson, R.S., S. Stewart, R.M. Brunner, and N. PINTER. 2010. Fire and vegetation history on Santa Rosa Island, Channel Islands, and long-term environmental change in southern California. Journal of Quaternary Science 25:782-797.

Carlson, C. 2016. Rare mammoth fossil found in national park. Ventura County Star, September 14, 2016. http:// www.vcstar.com/longform/news/special-reports/out doors/2016/09/14/clues-uncovered-life-long-extinct -mammoths-channel-islands/90306708

Cole, K.L., AND G. LiU. 1994. Holocene paleoecology of an estuary on Santa Rosa Island, California. Quaternary Research 41:326-335.

Collins, P.W. 2011. Bird checklist. Santa Barbara Museum of Natural History, Santa Barbara, CA. https://www .nps.gov/chis/learn/nature/upload/bird-list-allfinal.pdf

Dillon, A. 2018. Written communication. Email from Adam Dillon to Paula Power dated 25 May 2018.

FitzPatrick, F.A., I.R. Waite, P.J. D’Arconte, M.R. Meador, M.A. Maupin, and M.E. Gurtz. 1998. Revised methods for characterizing stream habitat in the National Water-Quality Assessment Program. U.S. Geological Survey Water-Resources Investigations Report 98-4052.

Gregory, K.J., AND D.E. Walling. 1973. Drainage basin. Form and process: a geomorphological approach. Edward Arnold, London.

Hendy, I.L. 2010. The paleoclimatic response of the southern Californian margin to the rapid climate change of the last $60 \mathrm{ka}$ : a regional overview. Quaternary International 215:62-73.

Horton, R.E. 1945. Erosional development of streams and their drainage basins-hydrophysical approach to quantitative morphology. Bulletin of the Geological Society of America 56:275-370.

[IPCC] Intergovernmental Panel on Climate Change. 2013. Climate change 2013: the physical science basis. Contribution of Working Group I to the Fifth Assessment Report of the Intergovernmental Panel on Climate Change. T.F. Stocker, D. Qin, G.K. Plattner, M. Tignor, S.K. Allen, J. Boschung, A. Nauels, Y. Xia, V. Bex, and P. Midgley, editors. Cambridge University Press.

Johnson, J.R., T.W. Stafford, H.O. Ajie, and D.P. Morris. 2000. Arlington Springs revisited. Pages 541-545 in D. Browne, K. Mitchell, and H. Chaney, editors, Proceedings of the Fifth California Islands Symposium. Santa Barbara Museum of Natural History, Santa Barbara, CA.

Johnson, L., AND D. RoDRiguez. 2001. Terrestrial vegetation monitoring Channel Islands National Park 1996-2000 report. Technical Report 01-06, National Park Service, Channel Islands National Park, 1901 Spinnaker Drive, Ventura, CA 93001.

Leopold, L.B., M.G. Wolman, and J.P. Miller. 1964. Fluvial processes in geomorphology. W.H. Freeman Co., Ltd., San Francisco, CA.

Livingston, D.S. 2016. The Channel Islands: a history of the islands within Channel Islands National Park. Historic Resource Study. Channel Islands National Park Headquarters, Ventura, CA.

Lombardo, C.A., and K.R. FaulKner. 1999. Eradication of feral pigs (Sus scrofa) from Santa Rosa Island, Channel Islands National Park, California. Pages 300-306 in D. Browne, K. Mitchell, and H. Chaney, editors, Proceedings of the Fifth California Islands Symposium. Santa Barbara Museum of Natural History, Santa Barbara, CA.

Minor, S.A., K.M. Schmidt, and D.R. Bedford. 2013. The dirt on Channel Islands National Park, California: Quaternary geologic mapping reveals new details of islands' tectonic and physiographic history. Geological Society of America Abstracts with Programs $45: 208$

Price, K., C.R. Jackson, A.J. Parker, T. Reitan, J. Dowd, AND M. CyTERsKi. 2011. Effects of watershed land use and geomorphology on stream low flows during severe drought conditions in the southern Blue Ridge Mountains, Georgia and North Carolina, United States. Water Resources Research 47: W02516. http://doi.org/10.1029/2010WR009340. 
Redmond, K., and G. McCurdy. 2005. Channel Islands National Park: design considerations for weather and climate monitoring. WRCC Report 05-02 July 2005. Western Regional Climate Center Desert Research Institute, Reno, NV. 111 pp.

Richards, R. 1997. Channel Islands National Park meteorological data sources for research applications. R.G. Richards Engineering, Helena, MT. Progress report to Channel Island National Park, $64 \mathrm{pp}$.

SChMidT, K.M., S.A. Minor, AND D.R. BEDFord. 2015. Quaternary geologic mapping of Channel Islands National Park, California. Science for Parks, Parks for Science, The Next Century, March 25-27, 2015, U.C. Berkeley, CA.

Schmidt, K.M., S.A. Minor, P. Power, and R. Rudolph. 2017. Geologic controls on surface-water hydrology on Santa Rosa Island, Channel Islands National Park, CA. Geological Society of America 2017 Annual Meeting, Seattle, Washington. 22-25 October 2017.

Schumann, R.R., J.S. Pigati, S. Jeffrey, and J.P. McGeeHIN. 2016. Fluvial system response to late Pleistocene-Holocene sea-level change on Santa Rosa Island, Channel Islands National Park, California. Geomorphology 268:322-340.

Strahler, A.N. 1957. Quantitative analysis of watershed geomorphology. Transactions of the American Geophysical Union 38:913-920.

Turner, D.S., AND M.D. List. 2007. Habitat mapping and conservation analysis to identify critical streams for
Arizona's native fish. Aquatic Conservation: Marine and Freshwater Ecosystems 17:737-748.

Turner, D.S., And H.E. Richter. 2011. Wet/dry mapping: using citizen scientists to monitor the extent of perennial surface flow in dryland regions. Environmental Management 47:497-505.

Vance-Borland, K., K. Burnett, and S. Clarke. 2009. Influence of mapping resolution on assessments of stream and streamside conditions: lessons from coastal Oregon, USA. Aquatic Conservation: Marine and Freshwater Ecosystems 19:252-263.

Wagner, J., M. Martin, K.R. Faulkner, S. Chaney, K. Noon, M. Denn, and J. Reiner. 2004. Riparian system recovery after removal of livestock from Santa Rosa Island, Channel Islands National Park, California. Technical Report NPS/NRWRD/NRTR2004-324. National Park Service, Water Resources Division, Fort Collins, CO; [accessed 24 May 2014]. www.nature.nps.gov/water/technicalReports/CHIS _RiparianReport-2004.pdf

Williams, A.P., C.J. STILl, D.T. Fischer, and S.W. LEaVITT. 2008. The influence of summertime fog and overcast clouds on the growth of a coastal Californian pine: a tree-ring study. Oecologia 156:601-611.

Received 2 March 2017

Revised 29 May 2018

Accepted 10 September 2018

Published online 31 December 2018 